\title{
Plastic for dinner? Observations of frequent debris ingestion by pelagic predatory fishes from the central North Pacific
}

\author{
C. Anela Choy*, Jeffrey C. Drazen \\ Department of Oceanography, University of Hawaii, 1000 Pope Road, Honolulu, Hawaii 96822, USA
}

\begin{abstract}
There have been numerous reports of plastic debris accumulation in surface waters of the central North Pacific Subtropical Gyre. Further, incidences have been reported of plastic ingestion by different marine organisms, including seabirds and small planktivorous fishes. Diet studies (2007 to 2012) of predatory pelagic fishes from this general region showed repeat observations of anthropogenic marine debris ingestion in 7 species $(n=595$ individuals examined). Incidence rates ranged from $<1 \%$ in Gempylus serpens to $58 \%$ in Lampris sp. (small-eye). Of all individuals $19 \%$ contained some form of marine debris, the majority of which was some form of plastic or fishing-related line. Surprisingly, species with the highest incidences of debris ingestion are thought to be primarily mesopelagic and unlikely to come into contact with surface waters containing known debris fields. Ingested debris pieces were found to be positively buoyant in seawater mimicking different depths. These observations are the first of their kind in scope and number, and suggest that more attention should be given to marine debris in subsurface waters as well as to poorly understood organismal and food web implications.
\end{abstract}

KEY WORDS: Anthropogenic marine debris - Plastic ingestion - Pelagic marine fishes · Mesopelagic fishes $\cdot$ North Pacific Subtropical Gyre $\cdot$ Opah $\cdot$ Lancetfish

\section{INTRODUCTION}

Large patches of anthropogenic marine debris have been reported from 2 of the ocean's largest features - the North Pacific and North Atlantic subtropical gyres (Moore et al. 2001, Law et al. 2010). Plastic and other anthropogenic debris have been found in the stomachs of a large number of marine organisms, including sea birds (e.g. Spear et al. 1995), invertebrates (Graham \& Thompson 2009), marine mammals (e.g. Eriksson \& Burton 2003), and planktivorous marine fishes (e.g. Boerger et al. 2010). Further studies documenting plastic debris throughout benthic, pelagic, and littoral marine environments provide direct evidence that plastic pollution is widespread, persistent, and an important issue of concern (e.g. McDermid \& McMullen

*Email: cachoy@hawaii.edu
2004, Thompson et al. 2004, Carson et al. 2011, Doyle et al. 2011).

The detrimental effects of plastic debris on marine biota include physical entanglement, decreased nutrition from intestinal blockage, and suffocation or decreased mobility (Derraik 2002, reviewed in Gregory 2009). Several studies have detailed ecotoxic effects of plastic debris in the marine environment, whereby plastic can serve as a vector for harmful organic contaminants such as polychlorinated biphenyls, aromatic and petroleum hydrocarbons, and organochlorine pesticides (reviewed in Teuten et al. 2009).

Despite the prevalence of studies documenting the environmental implications of plastic debris in the world's oceans there have been few reports of plastic ingestion by large marine fishes. Two recent studies from the North Pacific Subtropical Gyre reported

() The authors 2013. Open Access under Creative Commons by Attribution Licence. Use, distribution and reproduction are unrestricted. Authors and original publication must be credited. 
microplastic in the stomachs of planktivorous micronekton fishes, with approximately 9 to $32 \%$ of fishes examined containing plastic (Boerger et al. 2010, Davison \& Asch 2011). Reports of plastic ingestion in larger, higher trophic level pelagic fishes are sparse in the literature but include isolated reports from species such as dolphinfish, tunas, and the southern ocean moonfish (Hoss \& Settle 1990 and references therein, Jackson et al. 2000). We investigated ingestion of plastic and other anthropogenic debris in 7 species of large pelagic predatory fishes from open ocean waters of the central North Pacific Subtropical Gyre surrounding the Hawaiian Island Archipelago. Our study was based on incidental observations collected from multiyear diet studies, the primary objective of which was to describe regional food habits and trophic ecology. Our findings highlight 2 novel perspectives of the pervasive global plastic debris issue, namely the presence of plastic in some commonly consumed pelagic fish species and the suggestion that plastic pollution continues to extend into the deep ocean through interconnected epi- and mesopelagic food webs.

\section{MATERIALS AND METHODS}

Pelagic fish stomachs were collected at sea by trained longline fishery observers of the National
Oceanic and Atmospheric Administration's (NOAA) Hawaii Observer Program (as described in Choy et al. 2009) during 2007 to 2012. Longline fishery observers recorded species, fish length, sex (if known), and capture date while aboard commercial fishing vessels operating in the central North Pacific Ocean. Fish specimens were collected from both shallow and deep longline sets, which are typically set at $\sim 0-100$ and $\sim 100-400 \mathrm{~m}$, respectively (Bigelow et al. 2006). In accordance with NOAA's Fisheries Operations Data Confidentiality Policy, catch locations are not reported here. However, Fig. 1 details the general spatial coverage of the fishery, approximating the area from which fish in this study were sampled. Fishery observers sampled fish specimens randomly and opportunistically, and all stomach samples provided were examined in the laboratory.

Recent morphological and genetic studies suggest that opah species in the North Pacific are a complex of 2 species, referred to hereafter as Lampris sp. (bigeye) and Lampris sp. (small-eye) (J. Hyde pers. comm.). The tropical species of opah is currently known as Lampris guttatus. Stomachs of Lampris spp. are not commonly excised at sea, thus stomachs of these species were primarily sampled directly from local seafood wholesalers. While fish length and/or whole mass were available for these specimens, capture date and location were not. The large majority of

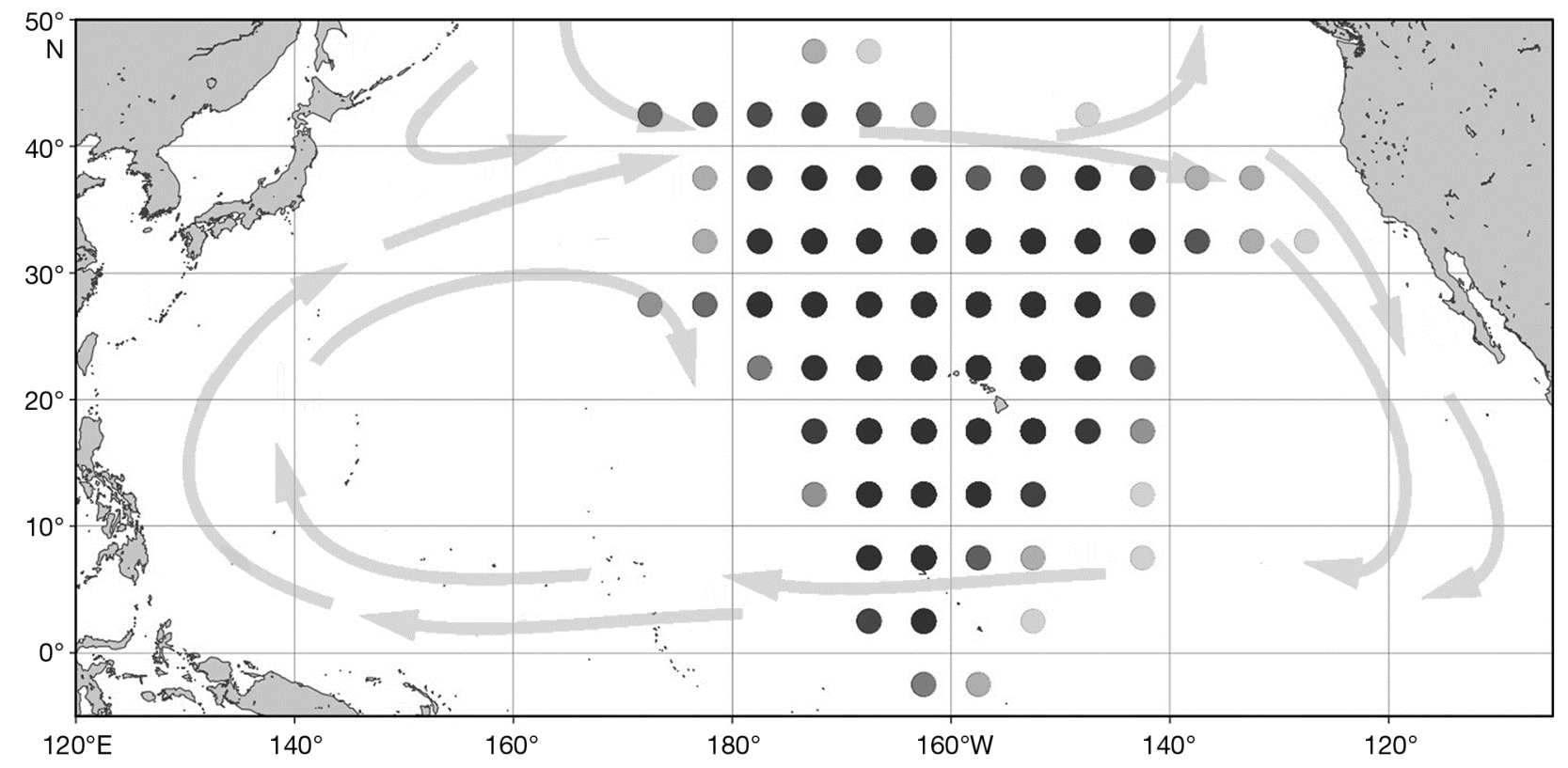

Fig. 1. General spatial coverage of the Hawaii Longline Fishery for the years 1990 to 2008. Qualitative fishing effort is shown by non-confidential $5^{\circ} \times 5^{\circ}$ locations from the NOAA Hawaii Longline Observer Program, where darker circles indicate more effort. The general oceanographic location of the North Pacific Subtropical Gyre is shown with grey arrows 
Lampris spp., Gempylus serpens, Alepisaurus ferox, and Lepidocybium flavobrunneum specimens were provided whole. No evidence of regurgitation of stomach contents (e.g. food items in esophagus or gills, everted stomachs) was noted.

In the laboratory, stomachs were defrosted and contents were sorted to the lowest taxonomic level possible using published literature and the advice of taxonomic experts. Ingested items (both prey and anthropogenic debris) were weighed to the nearest tenth of a gram, and their lengths measured if intact enough to do so. Stomach content examination methods were capable of detecting all visible size spectra of non-biological debris pieces, including microplastics $(<5 \mathrm{~mm})$. Dietary results are to be presented in a separate paper. Each individual piece of marine debris was assigned to 1 of 5 main categories: white and clear plastic, colored plastic, monofilament line (probably fishing related), uncategorized line and rope (probably related to nautical activities), and uncategorized and other. Uncategorized and other debris pieces did not fit into the other 4 categories or were unavailable for categorization (i.e. had been discarded before categorization was possible).

The fish species examined forage and move across different depth strata in the water column and not all are thought to come to the surface (see depth utilization data from fish tagging studies from the central North Pacific: Polovina et al. 2007, Howell et al. 2010, Abecassis et al. 2012). To investigate where in the water column debris pieces may have been ingested, the buoyancy of a representative subset of the plastic and other debris was evaluated (159 pieces from 58 individuals belonging to 3 fish species). These plastic and other anthropogenic debris pieces were weighed to the nearest hundredth of a gram, measured in the longest and widest dimensions to the nearest millimeter with calipers, and categorized by color and general debris type. Seawater representing 4 densities was made up using Instant Ocean sea salt and a controlled-temperature water circulator. Temperature and salinity properties representative of 4 different depth layers in the North Pacific Subtropical Gyre were extracted from the Hawaii Ocean Time Series HOT-DOGS online database (Table 1). $1.5 \mathrm{l}$ of each seawater type was placed into 21 glass beakers within controlled-temperature water baths; water was replaced halfway through each buoyancy trial (i.e. after approx. half of the subset of debris pieces were floated in that water type) to prevent potential changes in physical properties. Debris pieces were inspected for visible air bubbles and if present air bubbles were removed. Each debris piece was floated in each of the 4 water types for $60 \mathrm{~s}$. Pieces were dipped in distilled water to avoid crosscontamination between water types. Every 10th piece of debris was floated twice in each of the 4 water types; no buoyancy changes were observed across replicates. Temperature and salinity were measured at the start, middle and end of each trial for the 4 water types using a handheld conductivity meter (Orion 135) (Table 1).

\section{RESULTS}

The stomach contents of 595 individuals encompassing 10 species (6 families) were identified. Debris of anthropogenic origin was found within the stomachs of 112 individuals, i.e. 19\% of all fishes examined (Table 2). Percent frequency of ingestion among all 10 species ranged from 0 to $58 \%$, and was highest in the 2 Lampris spp. (43\% of Lampris sp.

Table 1. The 4 different seawater densities, representing 4 different depth layers used for the buoyancy trials. Target temperature and salinity properties were based on archived seawater properties from Hawaii Ocean Time Series HOT-DOGS online database (http://hahana.soest.hawaii.edu/hot/hot-dogs). Actual salinity and temperature measurements are presented as the average $( \pm \mathrm{SD})$ properties measured at the beginning, middle, and end of buoyancy trials. Calculated densities are based on Libes (1992) and on the average measured temperatures and salinities. Known density ranges $\left(\mathrm{g} \mathrm{ml}^{-1}\right)$ for common consumer virgin plastics: polypropylene $0.85-0.92$, low-density polyethylene $0.89-0.93$, high-density polyethylene $0.94-0.97$, polystyrene 0.94-0.97, polyvinyl chloride 1.16-1.41, polyethylene terephthalate 1.38-1.41 (from Morét-Ferguson et al. 2010)

\begin{tabular}{|lccccc|}
\hline Depth $(\mathrm{m})$ & $\begin{array}{c}\text { Target } \\
\text { salinity }\end{array}$ & $\begin{array}{c}\text { Target } \\
\text { temperature } \\
\left({ }^{\circ} \mathrm{C}\right)\end{array}$ & $\begin{array}{c}\text { Actual } \\
\text { salinity }\end{array}$ & $\begin{array}{c}\text { Actual } \\
\text { temperature } \\
\left({ }^{\circ} \mathrm{C}\right)\end{array}$ & $\begin{array}{c}\text { Calculated } \\
\text { density } \\
\left(\mathrm{g} \mathrm{cm} \mathrm{cm}^{-3}\right)\end{array}$ \\
\hline 0-50 (surface mixed layer) & 35.3 & 24.6 & $35.4(0.1)$ & $24.6(0.1)$ & 1.0234 \\
150-300 (salinity maximum) & 35.1 & 19.2 & $35.2(0.1)$ & $19.2(0.1)$ & 1.0250 \\
400-600 (salinity minimum) & 34.1 & 7.3 & $34.3(0.1)$ & $7.4(0.2)$ & 1.0267 \\
$1000-1200$ (mesopelagic base) & 34.5 & 5.6 & $34.8(0.1)$ & $5.6(0.1)$ & 1.0268 \\
\hline
\end{tabular}


Table 2. Pelagic fish species and sizes examined. Percent frequency of debris occurrence is the proportion of the individuals examined that contained plastic. Debris proportion is the gravimetric percentage of debris relative to total stomach contents, averaged across all individuals containing plastic. Note that the average total excludes species with only 1 stomach containing debris; instead, debris proportion is given in parentheses for the 1 stomach

\begin{tabular}{|c|c|c|c|c|}
\hline $\begin{array}{l}\text { Species } \\
\text { (common name) }\end{array}$ & $\begin{array}{l}\text { Number of } \\
\text { stomachs } \\
\text { examined }\end{array}$ & $\begin{array}{c}\text { Average fish } \\
\text { length } \pm \mathrm{SD}(\mathrm{cm}) \\
\text { [range] }\end{array}$ & $\begin{array}{c}\text { Number of } \\
\text { stomachs with debris } \\
{[\% \text { frequency }]}\end{array}$ & $\begin{array}{c}\text { Average debris } \\
\text { proportion } \pm \mathrm{SD} \\
\text { (\% mass) }\end{array}$ \\
\hline \multicolumn{5}{|l|}{ Family Alepisauridae } \\
\hline Alepisaurus ferox (longnosed lancetfish) & 144 & $92.2 \pm 33.9[20.2-153.0]$ & $43[30]$ & $31.2 \pm 38.6$ \\
\hline \multicolumn{5}{|l|}{ Family Coryphaenidae } \\
\hline Coryphaena hippurus (common dolphinfish) & 42 & $90.9 \pm 12.7[65.9-118.0]$ & $1[2]$ & $(0.1)$ \\
\hline \multicolumn{5}{|l|}{ Family Gempylidae } \\
\hline Gempylus serpens (snake mackerel) & 104 & $96.9 \pm 15.4[66.5-140.5]$ & $1[<1]$ & $(100)$ \\
\hline Lepidocybium flavobrunneum (Smith's escolar) & 45 & $62.4 \pm 17.7[27.0-111.0]$ & $0[0]$ & - \\
\hline \multicolumn{5}{|l|}{ Family Scombridae } \\
\hline Katsuwonus pelamis (skipjack tuna) & 29 & $71.5 \pm 8.3[46.0-81.0]$ & $0[0]$ & - \\
\hline Thunnus albacores (yellowfin tuna) & 26 & $99.6 \pm 26.9[52.9-157.6]$ & $0[0]$ & - \\
\hline Thunnus obesus (bigeye tuna) & 35 & $115.0 \pm 34.2[26.8-164.0]$ & 3 [9] & $33.4 \pm 57.7$ \\
\hline \multicolumn{5}{|l|}{ Family Lampridae } \\
\hline Lampris sp. (big-eye) (big-eye moonfish/opah) & 115 & $103.5 \pm 8.2[69.5-114.0]$ & 49 [43] & $17.2 \pm 26.2$ \\
\hline Lampris sp. (small-eye) (small-eye moonfish/opah) & 24 & $105.3 \pm 8.7[56.0-117.0]$ & $14[58]$ & $22.8 \pm 24.6$ \\
\hline \multicolumn{5}{|l|}{ Family Xiphiidae } \\
\hline Xiphias gladius (broadbill swordfish) & 31 & $145.4 \pm 28.7[77.0-209.0]$ & $1[3]$ & $(<0.1)$ \\
\hline Total & 595 & & $112[19]$ & $26.3 \pm 7.7$ \\
\hline
\end{tabular}

(big-eye) and $58 \%$ of Lampris sp. (small-eye)) and Alepisaurus ferox (30\%), all presumably mesopelagic fishes (Polovina et al. 2007). Of the 10 fish species examined, 3 contained no debris of anthropogenic origin.

Of the 7 species of fishes that ingested marine debris, anthropogenic items consisted mainly of assorted pieces of plastic and different types of fishing and nautical lines and rope pieces. A total of 262 individual pieces of plastic and other marine debris were found, and examples of some of these different types of debris are shown in Fig. 2. Categorical debris composition by species is shown in Fig. 3. Of the 3 species that ingested the largest number of debris pieces, Alepisaurus ferox seemed to favor white and clear plastic pieces while the 2 Lampris species did not seem to favor one type of debris over another (Fig. 3).

Within the debris subset of 159 individual pieces, debris length, width, and mass ranged widely (Table 3 ). On average Lampris sp. (small-eye) had one of the highest incidences of debris ingestion, and of the 3 species examined in detail, it ingested the highest number of pieces, which were on average the most massive $(2.2 \mathrm{~g})$ and the widest $(27.9 \mathrm{~mm}$ ) (Table 3$)$. For each of the 3 species, the large majority of these pieces were transparent, translucent or white in color $(50 \%$ for Alepisaurus

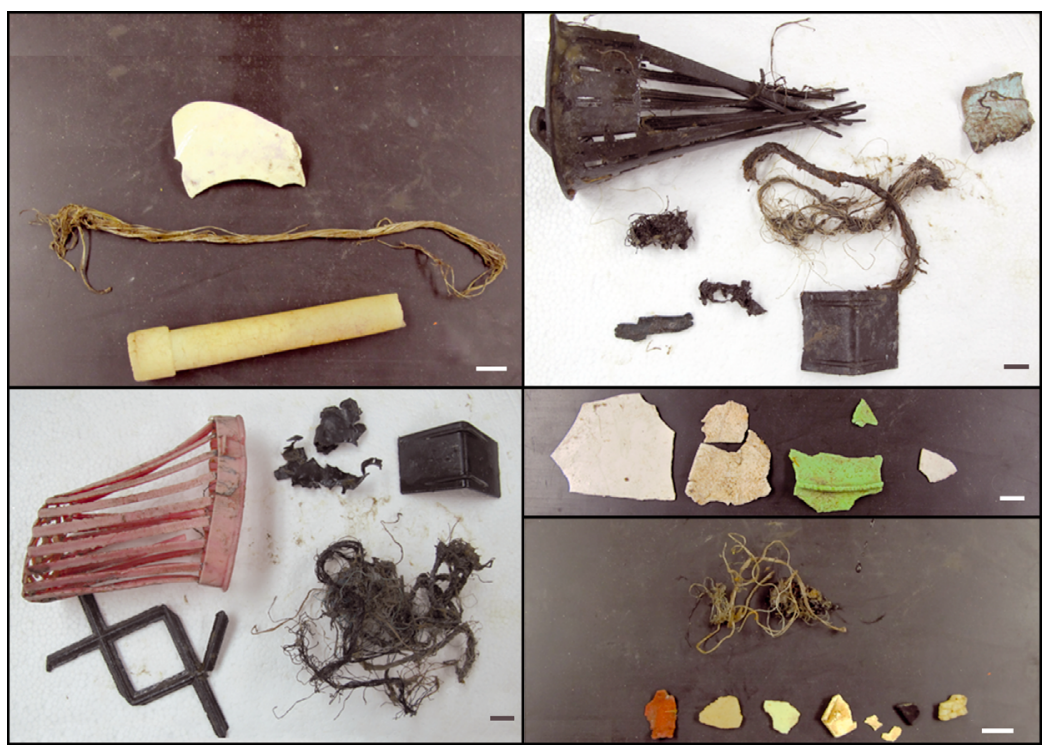

Fig. 2. Examples of anthropogenic marine debris found in Lampris spp. (all but top left image) and Alepisaurus ferox (top left image) stomachs. Each of the 5 images represents debris found within 1 individual stomach. Scale bars are $1 \mathrm{~cm}$ 

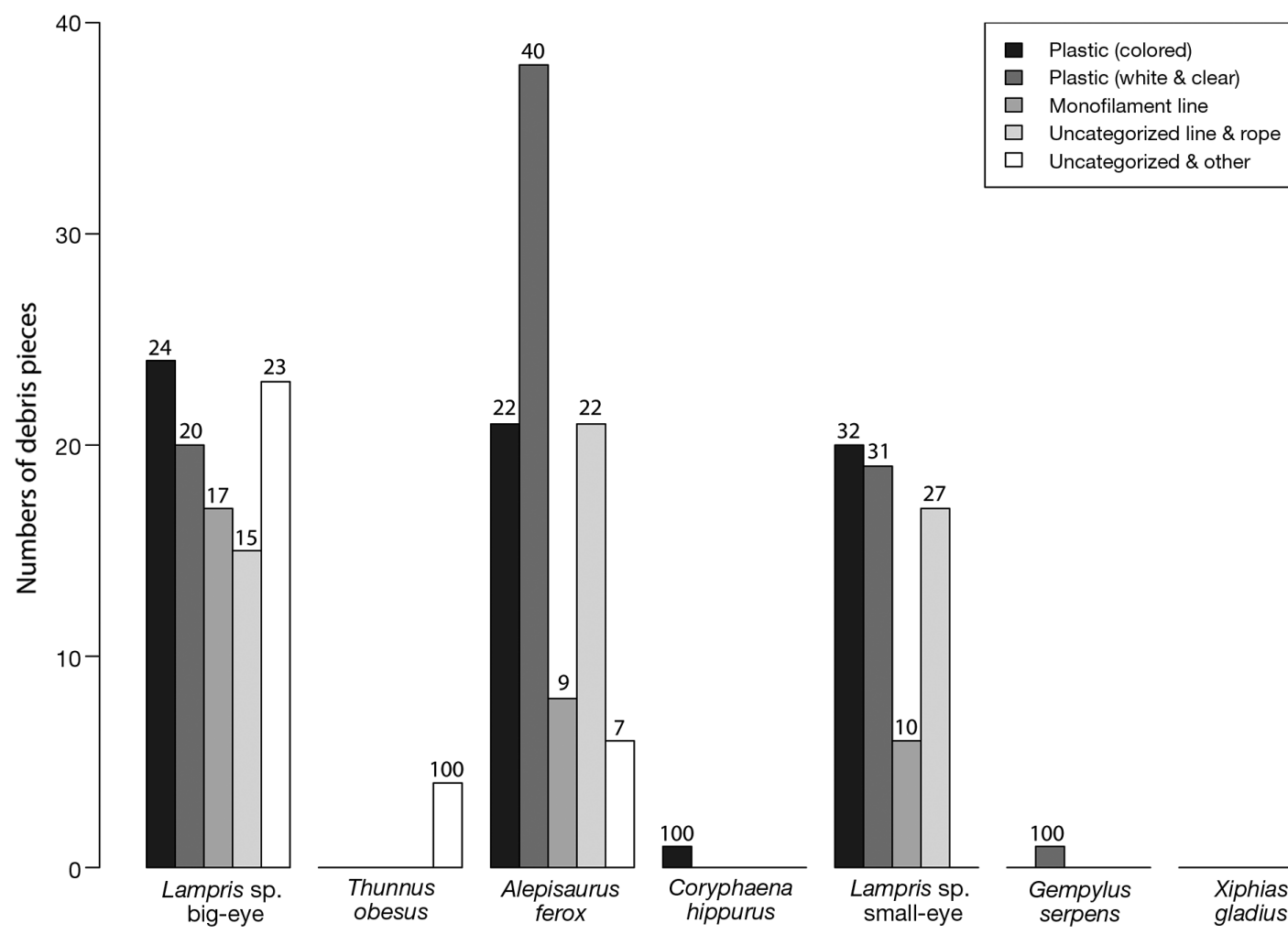

Fig. 3. Numbers of different types of marine debris, categorized per species. Numbers shown above vertical bars indicate relative proportions within each species

ferox, $45 \%$ for Lampris sp. (big-eye), and $31 \%$ for Lampris sp. (small-eye)). The second most common color of ingested debris was black $(14 \%$ for A. ferox, $22 \%$ for Lampris sp. (big-eye), and $31 \%$ for Lampris sp. (small-eye)).

All 159 debris pieces available for buoyancy trials floated in all 4 types of sea water representing depths of 0-50, 150-300, 400-600, and 1000-1200 m (Table 1). All pieces were floated as described above for $60 \mathrm{~s}$ per 4 water types, however we note that 2 of each type of debris (categories as described in Fig. 3) were left in each water type for longer than $10 \mathrm{~min}$ and all pieces remained positively buoyant. Furthermore, different types of debris were physically forced to the bottom of the beaker for all 4 water types and each piece immediately returned to the surface of the water.

\section{DISCUSSION}

Very few previous studies have specifically investigated debris ingestion in large marine fishes, but rather have documented such ingestion incidental to conventional food habit studies. Previous studies reporting plastic debris ingestion have focused on juvenile, coastal, and mesopelagic micronekton marine fishes (e.g. Carpenter et al. 1972, Boerger et al. 2010, Davison \& Asch 2011), all very distinct from the large, higher trophic level pelagic fishes studied here. A handful of previous studies have reported on plastic debris ingestion in trophically similar predatory mesopelagic fishes, however observations from most of these studies are based on relatively small sample sizes. For example, Jackson et al. (2000) exa-

Table 3. Detailed length, width and mass information for the subset of debris pieces

\begin{tabular}{|lcccccc|}
\hline Species & $\begin{array}{c}\text { Total number } \\
\text { of individuals } \\
\text { with debris }\end{array}$ & $\begin{array}{c}\text { Total number } \\
\text { of debris } \\
\text { pieces examined }\end{array}$ & $\begin{array}{c}\text { Average number } \\
\text { of pieces per } \\
\text { individual }\end{array}$ & $\begin{array}{c}\text { Average } \\
\text { debris length } \\
(\mathrm{mm})\end{array}$ & $\begin{array}{c}\text { Average } \\
\text { debris width } \\
(\mathrm{mm})\end{array}$ & $\begin{array}{c}\text { Average } \\
\text { debris mass } \\
(\mathrm{g})\end{array}$ \\
\hline Alepisaurus ferox & 24 & 64 & $2.7 \pm 2.0$ & $68.3 \pm 91.1$ & $17.7 \pm 21.5$ & $0.9 \pm 1.7$ \\
Lampris sp. (big-eye) & 29 & 65 & $2.3 \pm 1.6$ & $49.1 \pm 71.1$ & $10.6 \pm 10.3$ & $0.5 \pm 1.3$ \\
Lampris sp. (small-eye) & 5 & 30 & $5.8 \pm 3.9$ & $48.8 \pm 34.5$ & $27.9 \pm 21.0$ & $2.2 \pm 3.7$ \\
Total & $\mathbf{5 8}$ & $\mathbf{1 5 9}$ & $\mathbf{2 . 8} \pm \mathbf{2 . 2}$ & $\mathbf{5 6 . 8} \pm \mathbf{7 5 . 5}$ & $\mathbf{1 6 . 7} \pm \mathbf{1 8 . 6}$ & $\mathbf{1 . 0} \pm \mathbf{2 . 2}$ \\
\hline
\end{tabular}


mined 69 Lampris immaculatus individuals from the Patagonian Shelf and found plastic in $14 \%$ of the fishes. Kubota \& Uyeno (1970) reported 78 individual plastic pieces in the stomachs of 36 Alepisaurus ferox specimens, and Fujieda et al. (2008) reported plastic in 1 A. ferox individual. Our study reports observations of frequent plastic ingestion based on almost 600 individual fishes encompassing 10 species. With these considerable sample sizes we report some of the highest incidences of debris ingestion for similar marine fishes, with $30 \%$ of $A$. ferox, $43 \%$ of Lampris sp. (big-eye), and $58 \%$ of Lampris sp. (small-eye) individuals having ingested some form of anthropogenic debris (Table 2). These observations suggest that debris ingestion is not uncommon and may be more prevalent in certain species than previous observations have suggested.

The 3 species with the largest sample sizes and highest ingestion frequencies (Alepisaurus ferox and Lampris spp.) are considered to be primarily mesopelagic based on limited tagging and diet information. Polovina et al. (2007) described the diving behavior of 11 Lampris spp. (formerly L. guttatus) around Hawaii as inhabiting $\sim 50-150 \mathrm{~m}$ at night and 100-400 m during the day, with the shallowest and deepest depths recorded as 28 and $736 \mathrm{~m}$ respectively. There are no known tagging studies of A. ferox in the central North Pacific Subtropical Gyre, but the most important prey items from diet studies are primarily mesopelagic micronekton, including many non-migratory species (e.g. paralepidid and sternoptychid fishes, hyperiid amphipods) (Haedrich \& Nielsen 1966, Choy 2008). Thus, a central question arising from our findings is why mesopelagic predatory fishes are feeding on plastic debris of a presumably surface ocean origin.

There are several possible explanations for finding plastic pieces in the stomachs of fishes that forage primarily in the mesopelagic zone. First, the tagging and diet studies have incompletely characterized the movements of these fish and they do in fact at times feed in surface waters at night. The second is that the debris pieces are found in the predator's guts because their prey had first consumed them (i.e. secondary ingestion, as discussed in fur seals by Eriksson \& Burton (2003)). We can quickly discount this possibility because the plastic particles consumed by micronektonic fishes (i.e. the prey of Lampris spp. and Alepisaurus ferox) are typically $<3 \mathrm{~mm}$, much smaller than the average length of debris pieces we observed ( $>4 \mathrm{~cm}$, Table 3) (Boerger et al. 2010, Davison \& Asch 2011). In fact, many of the plastic pieces we found were as large or larger than other prey found in the guts of the predators (Choy 2008).

Third, it is conceivable that the plastic debris found was ingested at the surface when the fish were in the process of being hauled aboard the fishing vessels. If this were the case however, we would expect to see a greater prevalence of plastic in fish species other than Lampris spp. and Alepisaurus ferox. Although we cannot completely rule out the possibility that marine debris may be ingested in this manner, the uneven distribution of debris pieces across species that were collected with uniform methods largely argues against such a mechanism.

Another explanation is that the plastic and other debris were actually consumed at depth. As expected for plastic debris found offshore of landmasses, all plastic and other debris pieces were positively buoyant. There was no visible evidence of encrusting fauna that would have affected the inherent buoyancy of individual debris pieces. However, buoyancy was evaluated following consumption by the fishes and it is possible that buoyancy properties changed after ingestion. Buoyant plastics are known to sink when waterlogged and/or biofouled (Ye \& Andrady 1991, Barnes et al. 2009, Morét-Ferguson et al. 2010, Lobelle \& Cunliffe 2011). Plastics are found on the seabeds of all major oceans including the abyssal plains (Galgani et al. 1996, 2000, Barnes et al. 2009, Ramirez-Llodra et al. 2011, Bergmann \& Klages 2012) and are the most common debris found along the slope of the eastern Pacific (Keller et al. 2010). Thus it is reasonable to assume that plastics are present in the water column either as neutrally drifting pieces or slowly sinking particles. However, biofouling organisms would be digested in an acidic fish stomach after ingestion and the debris buoyancy properties would change. Davison \& Asch (2011) found that non-migrating planktivorous fishes ingested plastic, providing further suggestion that there is plastic in deep midwaters.

Finally, it is possible that wind-driven mixing, downwelling and/or currents act to carry plastic particles below surface waters, enabling ingestion by mesopelagic fishes. Kukulka et al. (2012) showed from trawl samples and mixing models that buoyant millimeter-sized particles of plastic were distributed throughout the upper wind-mixed water layer. Whether the larger particles identified in this study could also be physically mixed to depth remains uncertain.

Why fish would consume plastic or other types of marine debris is uncertain. It is often hypothesized that seabirds and marine turtles confuse plastic parti- 
cles with gelatinous prey (Carr 1987, Gramentz 1988) and the small plastic particles in zooplanktivorous fishes were predominantly blue, clear, and white, and of similar size to their main prey (Boerger et al. 2010). In our case, the differences in prevalence of plastic across species may afford some clues. Although they had the lowest sample sizes, the species that seemed to have the lowest incidences of plastic ingestion include Thunnus spp., Xiphias gladius, and Coryphaena hippurus. C. hippurus is a neustonic predator feeding predominantly on neustonic fishes, some squids and crustaceans (Olson \& Galván-Magaña 2002). Thunnus spp. and $X$. gladius principally consume active micronektonic squids and fishes (Holland \& Grubbs 2007, Choy 2008, Watanabe et al. 2009). While Lampris spp. also consume many micronekton fishes and squids (e.g. Jackson et al. 2000), specimens from the central North Pacific are known to also frequently prey on hyperiid amphipods (C. A. Choy et al. unpubl.). Alepisaurus ferox is also known to consume large numbers of mesopelagic hyperiid amphipods (Satoh 2004, Potier et al. 2007), namely the species Phrosina semilunata, Phronima sedentaria, and Platyscelus spp. identified from a study from the North Pacific (C. A. Choy et al. unpubl.). Many hyperiid amphipods associate with or are parasites of gelatinous zooplankton (Brusca 1973, Harbison et al. 1977, Gasca \& Haddock 2004, Gasca et al. 2007). As gelatinous prey are difficult to identify in stomach contents due to rapid digestion rates, it is unclear as to whether predatory fish consume just the amphipods and/or their gelatinous hosts. There is evidence that $A$. ferox commonly ingests gelatinous hosts (Satoh 2004, C. A. Choy et al. unpubl.) and thus it is possible that the 2 Lampris species and A. ferox confuse the plastic pieces for gelatinous prey. Additionally, almost half of the debris pieces found in the stomachs of $A$. ferox and the 2 Lampris species were transparent, translucent or white, providing a visual basis for possible confusion with common pelagic gelatinous animals such as salps or siphonophores.

While we focus on the differences in the prevalence of plastic and marine debris in shallow versus deeper-dwelling pelagic fishes there is certainly evidence for ingestion of marine debris by epipelagic predatory fishes (e.g. Coryphaena hippurus (Manooch et al. 1984), Thunnus albacares and T. atlanticus (Manooch \& Mason 1983)). Thus it is possible that the apparent positive buoyancy of the debris in this study indicates surface ingestion by mesopelagic fishes, perhaps during movement into shallower waters at night as suggested from very limited tagging data (Polovina et al. 2007, Kerstetter et al. 2008).
However, considering the relatively rare incidences of debris ingestion in epipelagic versus mesopelagic predatory fishes in this study and others, it is likely that debris pieces were ingested at subsurface depths. For example, Manooch et al. (1984) examined over 2000 epipelagic C. hippurus specimens and reported percent frequencies for anthropogenic debris below $1 \%$.

Our findings highlight 2 novel perspectives of the global plastic debris issue, namely the presence of plastic in some commonly consumed pelagic fish species and the suggestion that plastic pollution continues to extend into the deep ocean through interconnected epi- and mesopelagic food webs. Furthermore, we show that plastic ingestion in large pelagic fishes is more prevalent than previously suggested. The effects of plastic ingestion on the health of the fish remain uncertain, but could include gut blockage, particularly when large pieces are consumed (as in Fig. 2) and the transfer of chemical toxins (Teuten et al. 2009). Many plastics adsorb PCBs, organochlorine pesticides, polycyclic aromatic hydrocarbons, metals, and petroleum hydrocarbons, some of which may desorb in acidic stomachs resulting in uptake to the animal (Teuten et al. 2009, Van et al. 2012). Indeed, it has been shown that seabirds that ingested plastic had higher PCB concentrations in their fat tissues (Ryan et al. 1988), and seabird chicks fed plastics showed increasing PCB concentrations (Teuten et al. 2009). Given the global commercial importance of Lampris spp. and other large pelagic fishes (namely tunas and billfishes), future research might evaluate whether these fishes carry elevated chemical toxin burdens that may ultimately pose a risk to the seafood-consuming public.

Acknowledgements. This research was funded by Cooperative Agreement NA09OAR4320075 between the Joint Institute for Marine and Atmospheric Research (JIMAR) and the National Oceanic and Atmospheric Administration (NOAA) through the Pelagic Fisheries Research Program. We thank the NOAA longline observers for sample collection and L. Jantz and K. Busscher for assistance with observer data. J. Friedman, A. Hannides, and S. Ferron-Smith provided laboratory support. J. Polovina, M. McManus, G. Ravizza, B. Popp, and K. Nakamura provided helpful discussions. E. Portner, E. Aus, and B. Drake assisted with processing stomachs. V. Moriwake provided data assistance. H. Dulaiova, J. Kaminek, M. Merrifield, D. Lau. J. Hyde and A. Vetter kindly performed genetic identifications of Lampris spp. We thank 3 anonymous reviewers for their helpful criticisms to improve this manuscript. The views expressed herein are those of the authors and do not necessarily reflect the views of NOAA or any of its subdivisions. This study was carried out in accordance with the animal use protocols of the University of Hawai'i (protocol \#10-984). This is SOEST contribution number 8880 . 


\section{LITERATURE CITED}

Abecassis M, Dewar H, Hawn D, Polovina J (2012) Modeling swordfish daytime vertical habitat in the North Pacific Ocean from pop-up archival tags. Mar Ecol Prog Ser 452: 219-236

Barnes DKA, Galgani F, Thompson RC, Barlaz M (2009) Accumulation and fragmentation of plastic debris in global environments. Philos Trans R Soc Lond B 364: 1985-1998

Bergmann M, Klages M (2012) Increase of litter at the Arctic deep-sea observatory HAUSGARTEN. Mar Pollut Bull 64:2734-2741

Bigelow K, Musyl MK, Poisson F, Kleiber P (2006) Pelagic longline gear depth and shoaling. Fish Res 77:173-183

Boerger CM, Lattin GL, Moore SL, Moore CJ (2010) Plastic ingestion by planktivorous fishes in the North Pacific Central Gyre. Mar Pollut Bull 60:2275-2278

Brusca G (1973) Pelagic Amphipoda from the waters near Oahu Hawaii excluding the family Scinidae. Pac Sci 27: 8-27

> Carpenter EJ, Anderson SJ, Harvey GR, Miklas HP, Peck BB (1972) Polystyrene spherules in coastal waters. Science 178:749-750

> Carr A (1987) Impact of nondegradable marine debris on the ecology and survival outlook of sea turtles. Mar Pollut Bull 18:352-356

> Carson HS, Colbert SL, Kaylor MJ, McDermid KJ (2011) Small plastic debris changes water movement and heat transfer through beach sediments. Mar Pollut Bull 62: 1708-1713

Choy CA (2008) Mercury levels in Hawaiian predatory pelagic fishes and their prey as a function of depth and ecology. MSc thesis, University of Hawaii, Honolulu, HI

Choy CA, Popp BN, Kaneko JJ, Drazen JC (2009) The influence of depth on mercury levels in pelagic fishes and their prey. Proc Natl Acad Sci USA 106:13865-13869

> Davison P, Asch RG (2011) Plastic ingestion by mesopelagic fishes in the North Pacific Subtropical Gyre. Mar Ecol Prog Ser 432:173-180

Derraik JGB (2002) The pollution of the marine environment by plastic debris: a review. Mar Pollut Bull 44:842-852

> Doyle MJ, Watson W, Bowlin NM, Sheavly SB (2011) Plastic particles in coastal pelagic ecosystems of the Northeast Pacific ocean. Mar Environ Res 71:41-52

- Eriksson C, Burton H (2003) Origins and biological accumulation of small plastic particles in fur seals from Macquarie Island. Ambio 32:380-384

Fujieda S, Uchiyama M, Azuma T, Fukuda R, Arita Y (2008) Ingestion case of plastics by black marlin Makaira indica and lancetfish Alepisaurus ferox caught in the East Indian Ocean. Mem Fac Fish Kagoshima Univ 57: 47-48

Galgani F, Souplet A, Cadiou Y (1996) Accumulation of debris on the deep sea floor off the French Mediterranean coast. Mar Ecol Prog Ser 142:225-234

Galgani F, Leaute JP, Moguedet P, Souplet A and others (2000) Litter on the sea floor along European coasts. Mar Pollut Bull 40:516-527

Gasca R, Haddock SHD (2004) Associations between gelatinous zooplankton and hyperiid amphipods (Crustacea: Peracarida) in the Gulf of California. Hydrobiologia 530-531:529-535

Gasca R, Suarez-Morales E, Haddock SHD (2007) Symbiotic associations between crustaceans and gelatinous zoo- plankton in deep and surface waters off California. Mar Biol 151:233-242

Graham ER, Thompson JT (2009) Deposit- and suspensionfeeding sea cucumbers (Echinodermata) ingest plastic fragments. J Exp Mar Biol Ecol 368:22-29

Gramentz D (1988) Involvement of loggerhead turtle with the plastic metal and hydrocarbon pollution in the Central Mediterranean. Mar Pollut Bull 19:11-13

> Gregory MR (2009) Environmental implications of plastic debris in marine settings-entanglement ingestion smothering hangers-on hitch-hiking and alien invasions. Philos Trans R Soc Lond B 364:2013-2025

Haedrich RL, Nielsen JG (1966) Fishes eaten by Alepisaurus (Pisces, Iniomi) in the southeastern Pacific Ocean. DeepSea Res 13:909-919

Harbison GR, Bigs DC, Madin LP (1977) The associations of Amphipoda Hyperiidea with gelatinous zooplanktonII. Associations with Cnidaria Ctenophora and Radiolaria. Deep-Sea Res 24:465-468

Holland KN, Grubbs RD (2007) Fish visitors to seamounts: tunas and billfish at seamounts. In: Pitcher TJ, Morato T, Hart PJB, Clark MR and others (eds) Seamounts: ecology fisheries and conservation. Blackwell Publishing, Oxford, p 189-206

Hoss DE, Settle LR (1990) Ingestion of plastics by teleost fishes. In: Shomura RS, Godfrey ML (eds) Proceedings of the second international conference on marine debris. US Department of Commerce, NOAA Technical Memo, Honolulu, HI, p 693-709

> Howell EA, Hawn DR, Polovina JJ (2010) Spatiotemporal variability in bigeye tuna (Thunnus obesus) dive behavior in the central North Pacific Ocean. Prog Oceanogr 86: 81-93

Jackson GD, Buxton NG, George MJA (2000) Diet of the southern opah Lampris immaculatus on the Patagonian Shelf; the significance of the squid Moroteuthis ingens and anthropogenic plastic. Mar Ecol Prog Ser 206:261-271

Keller AA, Fruh EL, Johnson MM, Simon V, McGourty C (2010) Distribution and abundance of anthropogenic marine debris along the shelf and slope of the US West Coast. Mar Pollut Bull 60:692-700

Kerstetter DW, Rice PH, Snodgrass D, Prince ED (2008) Behavior of an escolar Lepidocybium flavobrunneum in the Windward Passage as determined from popup satellite archival tagging. Gulf Caribb Res 20:97-102

Kubota T, Uyeno T (1970) Food habits of lancetfish Alepisaurus ferox (Order Myctophiformes) in Suruga Bay Japan. Jpn J Ichthyol 17:22-28

Kukulka T, Proskurowski G, Morét-Ferguson S, Meyer DW, Law KL (2012) The effect of wind mixing on the vertical distribution of buoyant plastic debris. Geophys Res Lett 39:L07601, doi:10.1029/2012GL051116

> Law KL, Moret-Ferguson S, Maximenko NA, Proskurowski G, Peacock EE, Hafner J, Reddy CM (2010) Plastic accumulation in the North Atlantic Subtropical Gyre. Science 329:1185-1188

Libes SM (1992) An introduction to marine biogeochemistry. Wiley, New York, NY

Lobelle D, Cunliffe M (2011) Early microbial biofilm formation on marine plastic debris. Mar Pollut Bull 62:197-200

Manooch CS, Mason DL (1983) Comparative food studies of yellowfin in tuna, Thunnus albacares, and blackfin tuna, Thunnus atlanticus, (Pisces: Scombridae) from the southeastern and Gulf Coast of the United States. Acta Ichthyol Piscat 8:25-46 
Manooch CS, Mason DL, Nelson RS (1984) Food and gastrointestinal parasites of dolphin Coryphaena hippurus collected along the southeastern and gulf coasts of the United States. Bull Jpn Soc Sci Fish 50:1511-1525

McDermid KJ, McMullen TL (2004) Quantitative analysis of small-plastic debris on beaches in the Hawaiian archipelago. Mar Pollut Bull 48:790-794

Moore CJ, Moore SL, Leecaster MK, Weisberg SB (2001) A comparison of plastic and plankton in the North Pacific Central Gyre. Mar Pollut Bull 42:1297-1300

Morét-Ferguson S, Law KL, Proskurowski G, Murphy EK, Peacock EE, Reddy CM (2010) The size, mass, and composition of plastic debris in the western North Atlantic Ocean. Mar Pollut Bull 60:1873-1878

Olson RJ, Galván-Magaña F (2002) Food habits and consumption rates of common dolphinfish (Coryphaena hippurus) in the eastern Pacific Ocean. Fish Bull 100:279-298

Polovina JJ, Hawn D, Abecassis M (2007) Vertical movement and habitat of opah (Lampris guttatus) in the central North Pacific recorded with pop-up archival tags. Mar Biol 153:257-267

Potier M, Ménard F, Cherel Y, Lorrain A, Sabatié R, Marsac F (2007) Role of pelagic crustaceans in the diet of the longnose lancetfish Alepisaurus ferox in the Seychelles waters. Afr J Mar Sci 29:113-122

Ramirez-Llodra E, Tyler PA, Baker MC, Bergstad OA and others (2011) Man and the last great wilderness: human impact on the deep sea. PLoS ONE 6:e22588

Ryan PG, Connell AD, Gardener BD (1988) Plastic ingestion

Editorial responsibility: Jake Rice,

Ottawa, Ontario, Canada and PCBs in seabirds: Is there a relationship? Mar Pollut Bull 19:174-176

Satoh K (2004) Occurrence of Phronima sedentaria (Forskål 1775) (Amphipoda Hyperiidea) in the stomach of the longnose lancetfish Alepisaurus ferox (Lowe 1833) (Aulopiformes Alepisauroidei) in the North and tropical Atlantic Ocean. Crustaceana 77:729-739

Spear LB, Ainley DG, Ribic CA (1995) Incidence of plastic in seabirds from the tropical Pacific 1984-1991: relation with distribution of species, sex, age, season, year and body weight. Mar Environ Res 40:123-146

- Teuten EL, Saquing JM, Knappe DRU, Barlaz MA and others (2009) Transport and release of chemicals from plastics to the environment and to wildlife. Philos Trans R Soc Lond B 364:2027-2045

Thompson RC, Olsen Y, Mitchell RP, Davis A and others (2004) Lost at sea: Where is all the plastic? Science 304: 838

Van A, Rochman CM, Flores EM, Hill KL, Vargas E, Vargas SA, Hoh E (2012) Persistent organic pollutants in plastic marine debris found on beaches in San Diego, California. Chemosphere 86:258-263

> Watanabe H, Kubodera T, Yokawa K (2009) Feeding ecology of the swordfish Xiphias gladius in the subtropical region and transition zone of the western North Pacific. Mar Ecol Prog Ser 396:111-122

$>$ Ye S, Andrady AL (1991) Fouling of floating plastic debris under Biscayne Bay exposure conditions. Mar Pollut Bull 22:608-613

Submitted: November 2, 2012; Accepted: March 15, 2013 Proofs received from author(s): May 31, 2013 